Supplement of Atmos. Chem. Phys., 21, 10111-10132, 2021

https://doi.org/10.5194/acp-21-10111-2021-supplement

(C) Author(s) 2021. CC BY 4.0 License.

(c) (i)
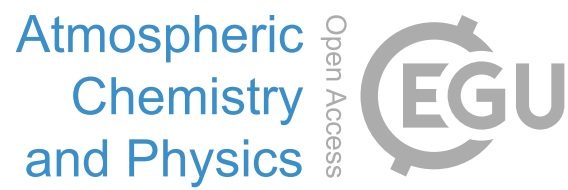

Supplement of

\title{
Air-sea exchange of acetone, acetaldehyde, DMS and isoprene at a UK coastal site
}

Daniel P. Phillips et al.

Correspondence to: Daniel P. Phillips (dph@pml.ac.uk) and Mingxi Yang (miya@pml.ac.uk)

The copyright of individual parts of the supplement might differ from the article licence. 
As described in the main text, we used simultaneous wind measurements from the PPAO ( 19 m) and coastal autonomous buoy $(4.9 \mathrm{~m}, \sim 4 \mathrm{~km} \mathrm{~S}-\mathrm{SW})$ to correct for flow acceleration due to the PPAO headland. Figure S1 shows the relationship between friction velocity and $U_{10}$, which agrees well with the Mackay and Yeun (1983) parameterisation and the COARE 3.5 model (Edson et al., 2013).

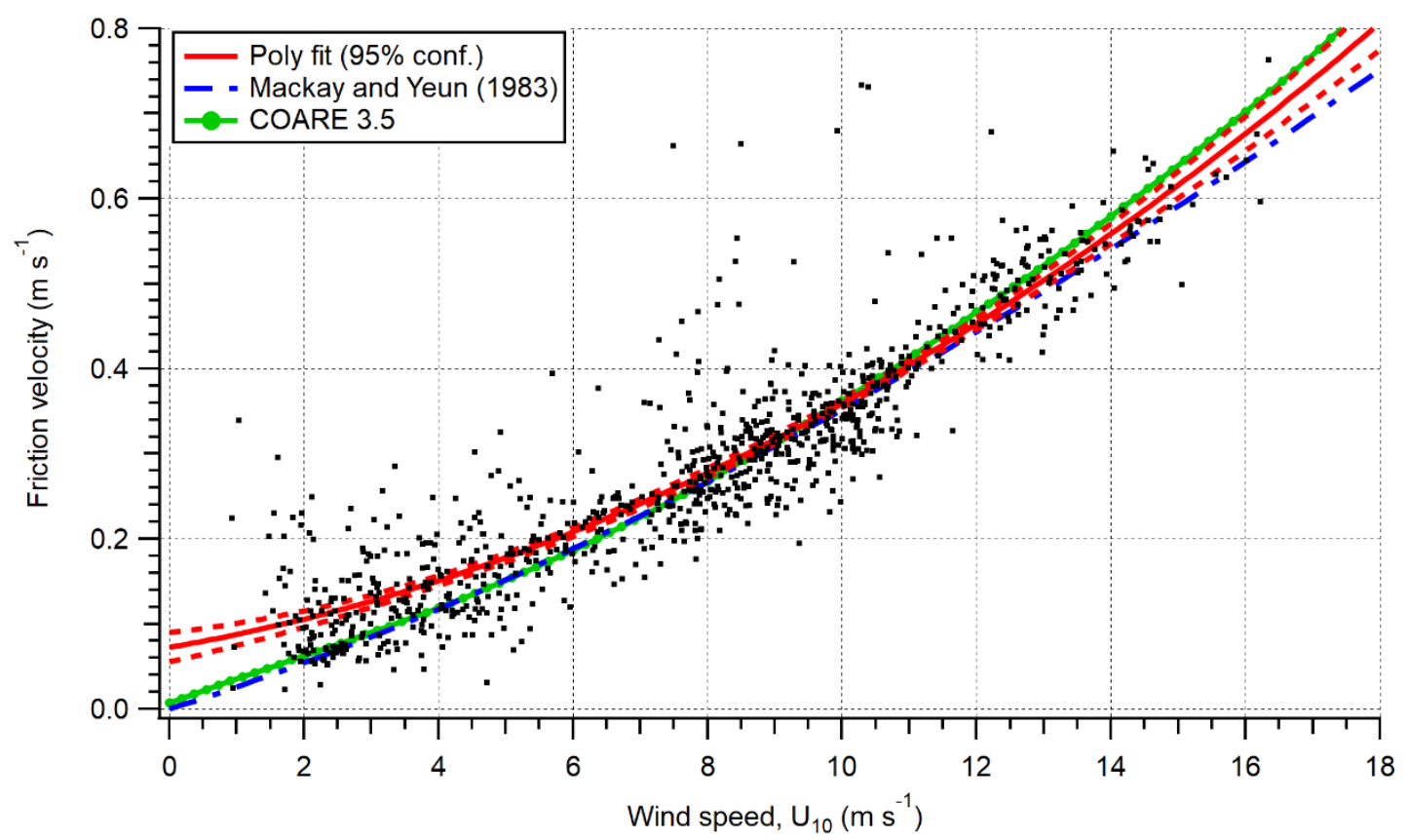

Figure S1: Comparison of measured friction velocity to wind speed (corrected to $10 \mathrm{~m}$ height). Data was filtered to remove influence of rain. Theoretical fit of Mackay and Yeun (1983) and COAREG 3.5 model (Edson et al., 2013) also shown.

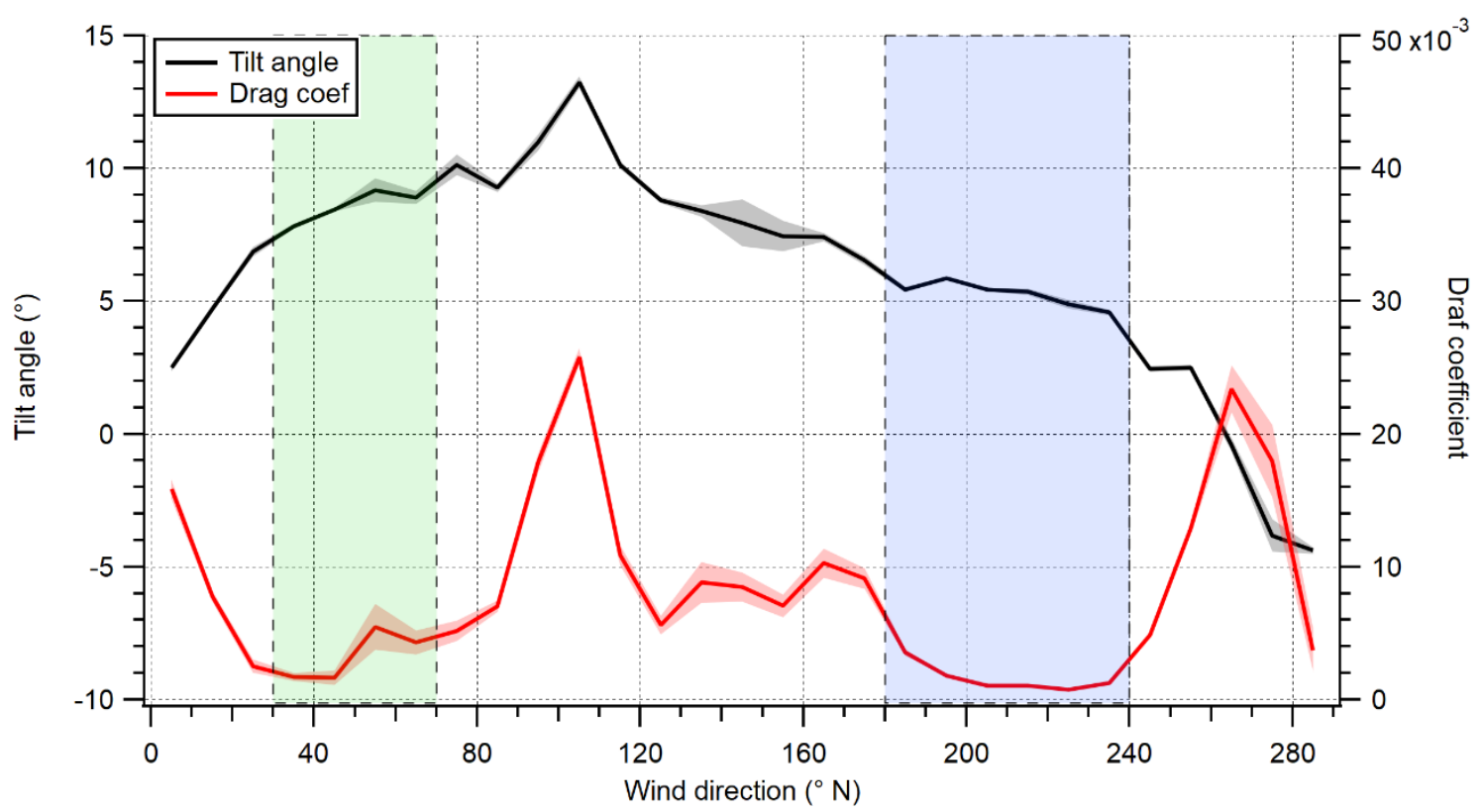

Figure S2: Vertical tilt angle correction (tilt of horizontal plane) applied to approaching winds and drag coefficient (> 3 m $\left.\mathrm{s}^{-1}\right)$, averaged into $10^{\circ}$ wind direction bins. Shaded region on lines is 1 standard error. The green and blue boxes represent the NE and SW wind sectors respectively.

Literature atmospheric carbonyl mixing rations from around our sample site were compared to those we observed. Figure S3 shows those mixing ratios plotted by coordinates. The sites and references are as follows: AMT (Yang et al., 2014), ATom4 (Wofsy et al., 2018), Mace Head (Lewis et al., 2005) and PML (Yang et al., 2013). 

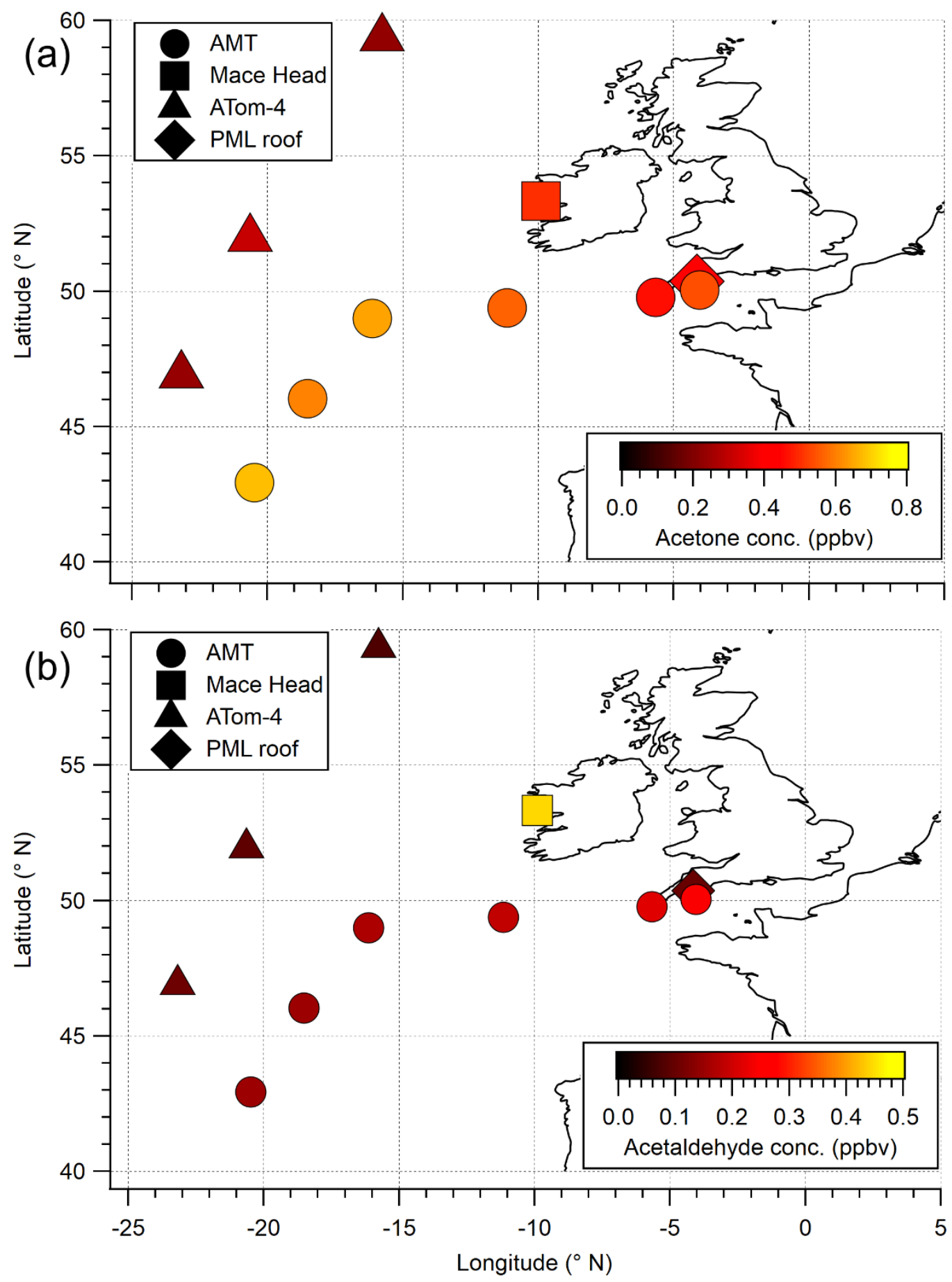

Figure S3: Location summary of atmospheric a) acetone and b) acetaldehyde mixing ratios discussed in Sect. 3.2 of the main text.

Wind trajectories were calculated using Hyplit model (https://www.ready.noaa.gov/HYSPLIT traj.php, last access: 16 November 2020) archive GDAS $0.5^{\circ}$ data for $01 / 05 / 18$ (the day with the most complete atmospheric mixing ratio measurement with satisfactory blanking) using the following settings; trajectory direction: backward; start time: 18/05/02 00; total run time:

20 72; new trajectory: 1; maximum trajectories: 24; level 1 height: 0 . The day of the 01/05/18 had clear sky in the morning but was overcast in the afternoon, as is evidenced by the Plymouth sun photometer data (https://www.westernchannelobservatory.org.uk/sunphotometer/). Furthermore, the NASA world view (https://worldview.earthdata.nasa.gov/, last access: 16 November 2020) shows a clear front that moves east during the 01/05/18. The lack of strong PAR and solar irradiance on the 01/05/18, when the majority of the TL SW data was collected,

25 is important considering that VOC lifetimes are dominated by photolysis and OH loss (i.e. acetaldehyde). The low PAR/solar irradiance will have meant that VOC lifetimes were extended and will have originated further upwind than on a clear day. 

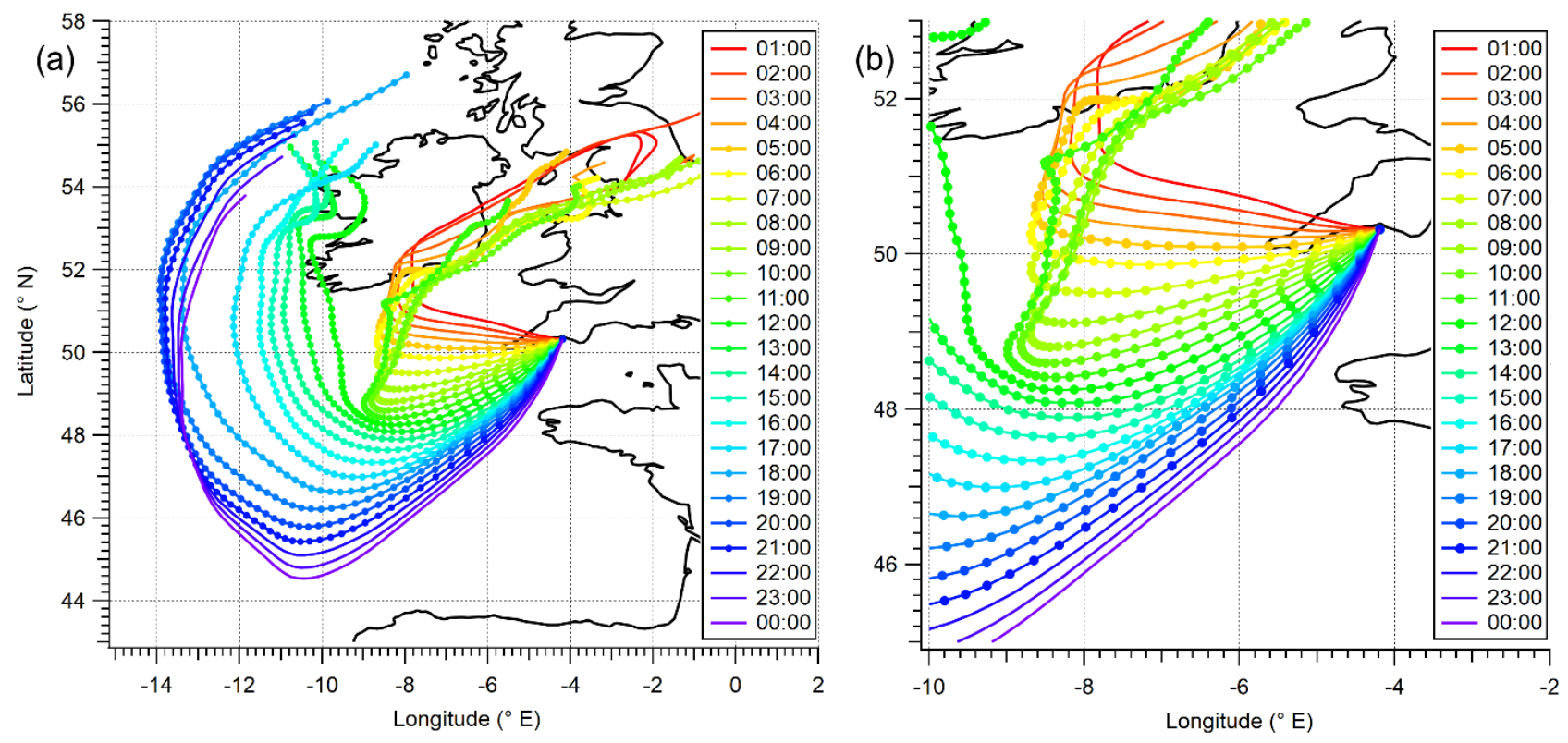

Figure S4: a) full and b) partial wind trajectories (72 $\mathrm{h}$ length) for a day (01/05/18) of near constant SW winds. Circles represent 1 $\mathrm{h}$ travel distances. Lines without circles correspond to periods removed by the quality control filtering for EC fluxes. The legend represents the hour of day the trajectory arrived at the observatory.

\section{References}

Edson, J. B., Jampana, V., Weller, R. A., Bigorre, S. P., Plueddemann, A. J., Fairall, C. W., Miller, S. D., Mahrt, L., Vickers, D. and Hersbach, H.: On the exchange of momentum over the open ocean, J. Phys. Oceanogr., 43(8), 1589-1610, doi:10.1175/JPO-D-12-0173.1, 2013.

Lewis, A. C., Hopkins, J. R., Carpenter, L. J., Stanton, J., Read, K. A. and Pilling, M. J.: Sources and sinks of acetone, methanol, and acetaldehyde in North Atlantic marine air, Atmos. Chem. Phys., 5(7), 1963-1974, doi:10.5194/acp-5-1963-2005, 2005.

Mackay, D. and Yeun, A. T. K.: Mass Transfer Coefficient Correlations for Volatilization of Organic Solutes from Water, Environ. Sci. Technol., 17(4), 211-217, doi:10.1021/es00110a006, 1983.

Wofsy, S. C., Afshar, S., Allen, H. M., Apel, E. C., Asher, E. C., Barletta, B., Bent, J., Bian, H., Biggs, B. C., Blake, D. R., Blake, N., Bourgeois, I., Brock, C. A., Brune, W. H., Budney, J. W., Bui, T. P., Butler, A., Campuzano-Jost, P., Chang, C. S., Chin, M., Commane, R., Correa, G., Crounse, J. D., Cullis, P. D., Daube, B. C., Day, D. A., Dean-Day, J. M., Dibb, J. E., DiGangi, J. P., Diskin, G. S., Dollner, M., Elkins, J. W., Erdesz, F., Fiore, A. M., Flynn, C. M., Froyd, K. D., Gesler, D. W., Hall, S. R., Hanisco, T. F., Hannun, R. A., Hills, A. J., Hintsa, E. J., Hoffman, A., Hornbrook, R. S., Huey, L. G., Hughes, S., Jimenez, J. L., Johnson, B. J., Katich, J. M., Keeling, R. F., Kim, M. J., Kupc, A., Lait, L. R., Lamarque, J.-F., Liu, J., McKain, K., Mclaughlin, R. J., Meinardi, S., Miller, D. O., Montzka, S. A., Moore, F. L., Morgan, E. J., Murphy, D. M., Murray, L. T., Nault, B. A., Neuman, J. A., Newman, P. A., Nicely, J. M., Pan, X., Paplawsky, W., Peischl, J., Prather, M. J., Price, D. J., Ray, E. A., Reeves, J. M., Richardson, M., Rollins, A. W., Rosenlof, K. H., Ryerson, T. B., Scheuer, E., Schill, G. P., Schroder, J. C., Schwarz, J. P., St.Clair, J. M., Steenrod, S. D., Stephens, B. B., Strode, S. A., Sweeney, C., Tanner, D., Teng, A. P., Thames, A. B., Thompson, C. R., Ullmann, K., Veres, P. R., Vieznor, N., Wagner, N. L., Watt, A., Weber, R., Weinzierl, B., et al.: ATom: Merged Atmospheric Chemistry, Trace Gases, and Aerosols, doi:10.3334/ORNLDAAC/1581, 2018.

Yang, M., Beale, R., Smyth, T. J. and Blomquist, B. W.: Measurements of OVOC fluxes by eddy covariance using a protontransfer- reaction mass spectrometer - method development at a coastal site, Atmos. Chem. Phys., 13(13), 6165-6184, doi:10.5194/acp-13-6165-2013, 2013.

55 Yang, M., Beale, R., Liss, P. S., Johnson, M. T., Blomquist, B. W. and Nightingale, P. D.: Air-sea fluxes of oxygenated volatile organic compounds across the Atlantic Ocean, Atmos. Chem. Phys., 14(14), 7499-7517, doi:10.5194/acp-14-74992014, 2014. 